\title{
Autopsy based profile of death in burn cases- One year prospective study
}

\author{
Devesh Pateria ${ }^{1}$, P.S. Thakur², Rahul Agrawal ${ }^{3, *}$, B.K. Singh ${ }^{4}$, Jitendra Tomar ${ }^{5}$ \\ ${ }^{1,3}$ P.G. Resident, ${ }^{2}$ Professor and Head, ${ }^{4}$ Associate Professor, ${ }^{5}$ Assistant Professor, Dept. of Forensic Medicine \& Toxicology, M.G.M. \\ Medical College \& M.Y. Hospital, Indore, Madhya Pradesh, India \\ *Corresponding Author: Rahul Agrawal \\ Email: dr.rahulagrawa108@gmail.com
}

\begin{abstract}
Fire, since ancient times have kept amusing mankind in various ways. Perhaps it is one of the greatest inventions in the history of all times. It has helped humans to evolve but if mishandled can lead to serious consequences. It is commonly encountered as medical emergencies in any hospital in India. It has continuously effected population resulting in form of prolonged morbidity, disability and even as death of the individual ultimately leading to loss to individual's family, society and to the state. The present prospective study was carried out in the Department of Forensic Medicine \& Toxicology, M.G.M. Medical College \& M.Y. Hospital, Indore during the period from 1st August 2017 to 31 st July 2018 which includes a total of 277 cases of death due to burn injuries, brought to the mortuary of the hospital for medicolegal postmortem examination. During the study period burn in female victims was more evident with accounting 178 (64.3\%) cases as compared to males $99(35.7 \%)$. 31-40 years age group in males i.e. $24(8.6 \%)$ was most effected and minimum in the age group of 0-10 years i.e. $5(1.8 \%)$ whereas in females maximum incidence was noted in the age group of 21-30 years i.e. $80(28.8 \%)$ and minimum 5 cases were reported in age group of above 61 years. The minimum age to suffer burns was 1 year which was a male child and maximum age was 80 years which was a male patient. Various other demographic aspects of deaths due to burns were included as objective in the study and ultimately provided some remedial measures in order to cope up with current scenario.
\end{abstract}

Keywords: Burn, Autopsy, Demography, Body surface area, Manner of death.

\section{Introduction}

Burn is an injury which is caused by application of heat by conduction, radiation or chemical substance to the external or internal surface of the body which causes destruction of tissue. ${ }^{1}$ Deaths are only a part of the problem, for every person who dies as a result of their burns; many more are left with lifelong disabilities and disfigurements.

By law all dry heat lesions have been designated as burns. ${ }^{2}$ Burn injuries have long been described as among the most serious injuries that may afflict a human being. ${ }^{3}$ Burn is a unique but significant mode of suicide and homicide everywhere in the world. Burns are the fourth most common type of trauma worldwide, following traffic accidents; falls and interpersonal violence. ${ }^{4}$ The most common cause of flame burns in modern society is accident. ${ }^{5,6}$

Local injury from heat occurs when an external source of heat raises the temperature of tissue above approximately 44.0 degree centigrade for long enough to damage the tissue. Extremes of age are more vulnerable to such injuries. However in India, it is most commonly seen in younger age group and is most common it female as against in developed countries where it is most common in males as is true with any form of trauma.

\section{Materials and Methods}

The present prospective study was carried out in the Department of Forensic Medicine \& Toxicology, M.G.M. Medical College \& M.Y. Hospital, Indore (M.P.) during the period from 1st August 2017 to 31st July 2018 and analysis a total of 277 cases of burn death, brought to the mortuary of the hospital for medico-legal postmortem examination.

Details of the cases were collected from the police papers, the inquest reports, hospital records and during autopsy like age, sex, marital status, percentage and total body surface area of burn etc. the information was compiled, tabulated and analyzed.

\section{Observation and Result}

In the current study, a total of 277 medico legal autopsy was performed in the mortuary of Department of Forensic Medicine \& toxicology at M.G.M. Medical College \& M.Y. Hospital, Indore during the period from 1st August 2017 to 31 st July 2018.

During the study period burn in female victims was more evident with accounting $178(64.3 \%)$ cases as compared to males 99 (35.7\%), and male: female ratio was 1:1.79 (Fig. 1). 31-40 years age group in males i.e. 24 $(8.6 \%)$ was most effected and minimum in the age group of $0-10$ years i.e. $5(1.8 \%)$ whereas in females maximum incidence was noted in the age group of 21-30 years i.e. 80 $(28.8 \%)$ and minimum 5 cases were reported in age group of above 61 years. The minimum age to suffer burns was 1 year which was a male child and maximum age was 80 years which was a male patient. (Fig. 2)

Married victims were 220 (79.4\%) and 57 (20.5\%) were unmarried with married-unmarried ratio of 3.85:1 (Fig. 3). In present study out of all burn cases, in 17 cases $(6.1 \%)$ presence of carbon soot particles in trachea was noted (Fig. 4 ) and in 89 cases $(32.1 \%)$ kerosene odour was coming out from body. (Fig. 5)

In present study 35 cases (12.6\%) were caused by electric spark burn, with predominance of male with 23 cases $(8.3 \%)$ as compared to female with 12 cases (4.3\%). (Fig. 6)

In majority of burn cases (63.8\% cases), total body surface area involved was between $40-70 \%$, followed by $22.3 \%$ cases with $70-90 \%$ body surface area. Only $3.6 \%$ 
cases died with total body surface area less than $30 \%$. (Table 1)

In areas of body affected due to burn, upper extremities were most commonly affected i.e. in 253 (91.3\%) cases, followed by head, neck and face in $247(89.1 \%)$ cases. Chest \& abdomen were involved in 221 (79.7\%) cases and involvement of genitalia was $47(16.9 \%)$ cases only. (Table 2)

Alleged manner of death due to burn in present study was accidental in nature in 205 cases $(73.9 \%)$ followed by suicidal in 56 cases $(20.2 \%)$ and only 6 cases $(2.1 \%)$ were homicidal in nature. (Table 3 )

Table 1: Body surface area involved

\begin{tabular}{|l|c|c|c|}
\hline BSA Involved & Male (\%) & Female (\%) & Total (\%) \\
\hline $10-20 \%$ & $0(0.0 \%)$ & $0(0.0 \%)$ & $0(0.0 \%)$ \\
\hline $20-30 \%$ & $4(1.4 \%)$ & $6(2.1 \%)$ & $10(3.6 \%)$ \\
\hline $3040 \%$ & $8(2.8 \%)$ & $10(3.6 \%)$ & $18(6.4 \%)$ \\
\hline $40-50 \%$ & $17(6.1 \%)$ & $21(7.5 \%)$ & $38(13.7 \%)$ \\
\hline $50-60 \%$ & $27(9.7 \%)$ & $52(18.7 \%)$ & $79(28.5 \%)$ \\
\hline $60-70 \%$ & $18(6.4 \%)$ & $42(15.1 \%)$ & $60(21.6 \%)$ \\
\hline $70-80 \%$ & $13(4.6 \%)$ & $27(9.7 \%)$ & $40(14.4 \%)$ \\
\hline $80-90 \%$ & $9(3.2 \%)$ & $14(5.0 \%)$ & $22(7.9 \%)$ \\
\hline $90-100 \%$ & $3(1.0 \%)$ & $6(2.1 \%)$ & $9(3.2 \%)$ \\
\hline Total & 99 & 178 & 277 \\
\hline
\end{tabular}

Table 2: Distribution of burn injuries on the body $(\mathrm{N}=277)$

\begin{tabular}{|l|c|c|}
\hline \multicolumn{1}{|c|}{ Area of body burnt } & Total no. of cases & Percentage (\%) \\
\hline Head, neck, face & 247 & $89.1 \%$ \\
\hline Chest, abdomen & 221 & $79.7 \%$ \\
\hline Back & 198 & $71.4 \%$ \\
\hline Upper extrimity & 253 & $91.3 \%$ \\
\hline Lower extrimity & 180 & $64.9 \%$ \\
\hline Genitalia & 47 & $16.9 \%$ \\
\hline
\end{tabular}

Table 3: Alleged manner of incidence

\begin{tabular}{|c|c|c|c|c|c|}
\hline \multicolumn{2}{|c|}{ Accidental (\%) } & \multicolumn{2}{c|}{ Suicidal (\%) } & \multicolumn{2}{c|}{ Homicidal (\%) } \\
\hline Male & Female & Male & Female & Male & Female \\
\hline $70(25.2 \%)$ & $135(48.7 \%)$ & $15(5.4 \%)$ & $41(14.8 \%)$ & $4(1.4 \%)$ & $2(0.7 \%)$ \\
\hline
\end{tabular}

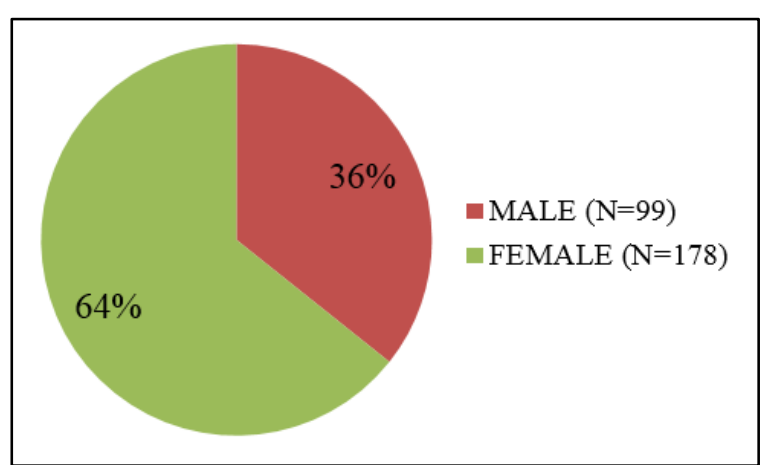

Fig. 1: Sex wise distribution of burns

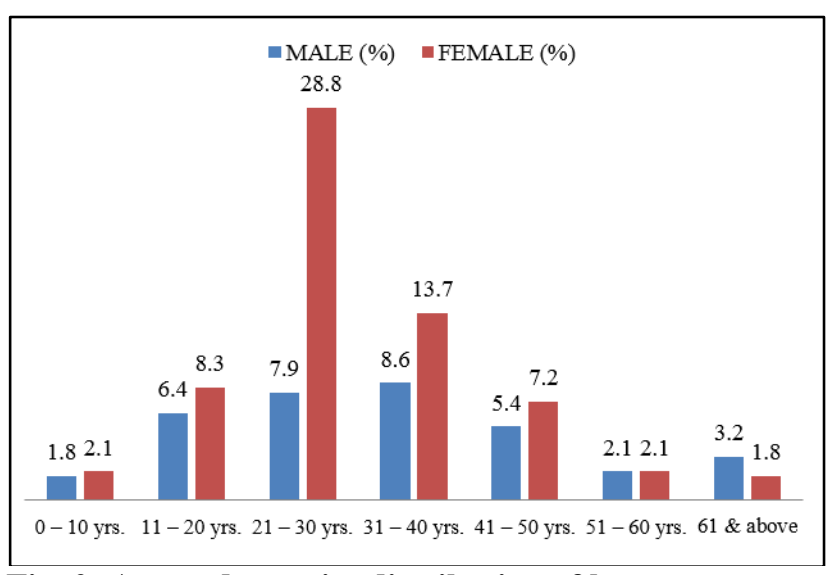

Fig. 2: Age and sex wise distribution of burn cases 


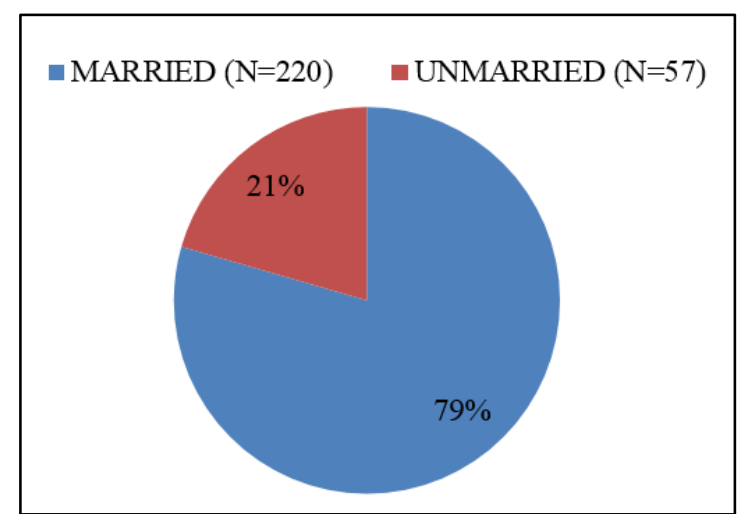

Fig. 3: Distribution of burn in relation to marital status

- TOTAL NO. OF CASES $(\mathrm{N}=277)$ " SOOT PARTICLES $(\mathrm{N}=17)$

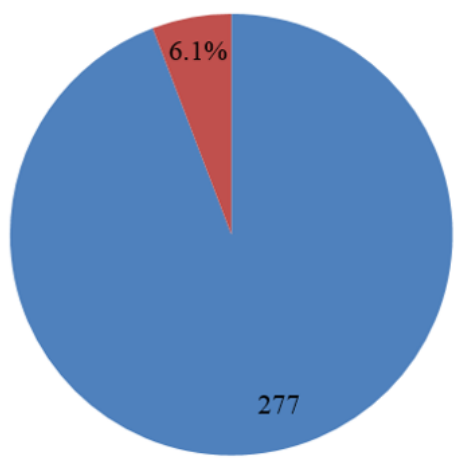

Fig. 4: Presence of soot particles in trachea

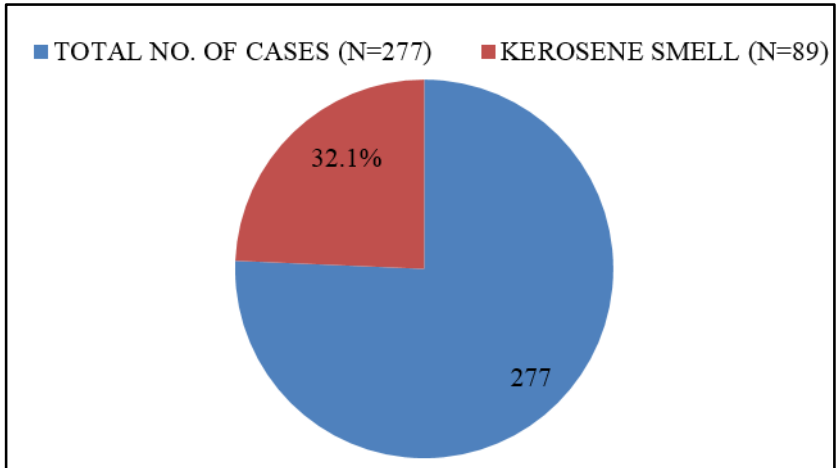

Fig. 5: Kerosene smell evident from body

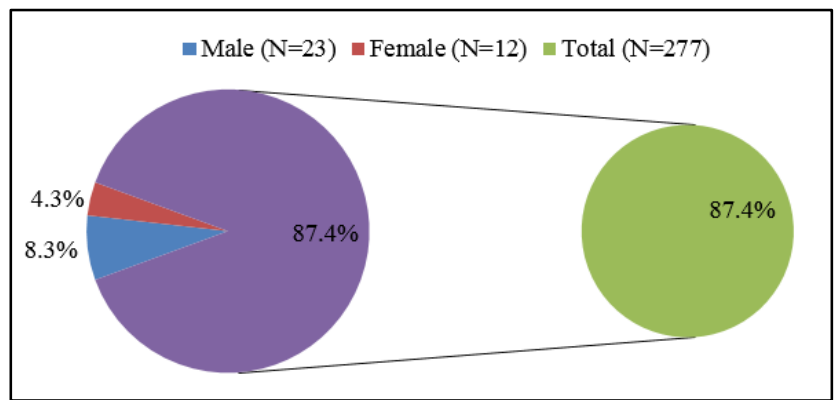

Fig. 6: Electric spark burn injury

\section{Discussion}

In the present study, there is a predominance of female victims than males in burn cases and a majority of them were in the reproductive age group 21-30 years, which is similar to the findings of other similar studies. ${ }^{7-10}$

Soot particles are found in trachea in $6.1 \%$ of cases, which is different from the finding of Das $\mathrm{KC},{ }^{8}$ who found soot particles in trachea in $18.05 \%$ cases and Nath $\mathrm{D}^{9}$ found in $34.07 \%$ cases and Mazumdar $\mathrm{A}^{10}$ found soot particles in trachea in $19 \%$ cases.

In the present study, majority $(63.8 \%)$ of the victims had $40-70 \%$ of total body surface area (TBSA) burn. Studies from Angola ${ }^{11}$ revealed $100 \%$ mortality over $40 \%$ TBSA, and similarly $80 \%$ mortality rate in burn over $40-50 \%$ TBSA has been reported from Jaipur. ${ }^{12}$

$220(79.4 \%)$ victims were married and 57 (20.5\%) were unmarried. Of the females 158 (57.0) were married and 20 $(7.2 \%)$ were unmarried in contrast to males $62(22.3 \%)$ were married and $37(13.3 \%)$ were unmarried. Other studies also reported similar finding, ${ }^{7,13-16}$ this is because of their marital maladjustment and bride burning cases in recently married females or may be because of the fact that married females are more involved in cooking.

In present study upper extremities were most commonly affected in $253(91.3 \%)$ cases, followed by head, neck and face in $247(89.1 \%)$. Similar findings were observed in the study done by Chawla R et a ${ }^{17}$ and Ande JD et $\mathrm{al}^{18}$ with most of the cases involving upper limbs (93.5\%), followed by chest and abdomen (86.11\%), lower limbs $(63.8 \%)$ and genitalia $(14.81 \%)$. In contrast to the present study, Buchade D et $\mathrm{al}^{7}$ found that Head, face \& neck region was most commonly affected in 206 (86.91\%) cases, followed by chest in $174(73.41 \%)$ cases.

In the present study kerosene smell was evident in 89 (32.1\%) cases out of total 277 cases. This may be due to reason of extensive use of kerosene in household purposes for cooking and in lighting lamps in the evening and night in the rural areas as there is less availability of cooking gas and electricity in rural areas. Whereas on the contrary Chaudhary BL et $\mathrm{al}^{19}$ in their study observed smell of kerosene in only $4 \%$ cases.

In the present study alleged homicidal burn was found in $6(2.1 \%)$ cases out of total 277 cases. $4(1.4 \%)$ cases in males and in females it was $2(0.7 \%)$. In this study most of injuries are accidental in nature i.e. 205 (74.0\%), followed by suicidal burn $56(20.2 \%)$. Chaudhary BL et $\mathrm{al}^{19}$ found accidental burns in $72.94 \%$ cases, followed by suicidal in $17.39 \%$ and homicidal in $9.66 \%$ cases. Buchade D et al, ${ }^{7}$ also found that most common manner of the burn was accidental in 147 (62.02\%) cases, followed by suicidal in 62 $(26.16 \%)$ and homicidal in $28(11.82 \%)$ cases. Mangal HM et $\mathrm{al}^{13}$ conducted study on 300 cases and observed that in most of the burn victims the manner of death was accidental in 183 cases (61\%), followed by suicidal in 105 cases (35\%) and homicidal in only $12(4 \%)$ cases. Similar observations were seen by Das $\mathrm{KC}^{8}$ and Bangal RS. ${ }^{20}$ 


\section{Conclusion}

In this study, more than half of the victims died of burn injuries were married women. Despite the modernization, the domestic fire is the major cause of burns with maximum involvement of female.

The government along with various working groups and the NGOs, including the doctors need to put in more sincere effort. The NGOs and social groups must arrange a periodic effort in educating the rural peoples. Steps should be taken not only to minimize burn mortality but also to prevent and reduce their incidence at least in cases where human errors and human greed plays a role.

The most important step in reducing the burn incidence is through mass education. Following the safety instructions like putting the lights off while going out, wearing tight and cotton cloths while cooking, not leaving a fire source unattended etc. will definitely help to reduce the incidence of burn injuries, as most of the accidental burn cases are preventable. The present study is concluded with the hope that the given suggestions will help in reducing the number of burn injuries.

\section{Conflict of Interest: Nil.}

\section{References}

1. Reddy K.S.N. Thermal Deaths', The Essentials of Forensic Medicine and Toxicology, 2017, 34th ed, p297.

2. Pillay V. V. 'Injuries due to Heat, Lightening, Electrocution and radiation' $2017,18^{\text {th }}$ ed, p270.

3. Reddy K. S. N. 'Thermal Deaths', The Essentials of Forensic Medicine and Toxicology, 2009, 29th ed, Devi K. Suguna, Hyderabad, p283.

4. Saukko Pekka, Knight Bernard. Burns and Scalds, Knight's Forensic Pathology, 2004, 3rd ed, Oxford University Press Inc, New York, p322.

5. Van Rijn. J.L. Olga, Bouter. L.M., Meertens R.M. The aetiology of burns in developed countries, 1989[4], available from www. Aetiology of burn injuries. Com.

6. Vij Krishan. "Thermal Deaths", Text Book of Forensic Medicine and Toxicology, 2008; 5th ed, Elsevier, A Division of Reed Elsevier India Pvt. Ltd.p159.

7. Buchade D, Kukde H, Dere R, Savardekar R. Pattern of Burn Cases Brought to Morgue, Sion Hospital Mumbai, A Two Year Study. JIAFM. 2011;33(4):309-310.

8. Das. K.C. A study of burn cases in medico-legal autopsy. MD thesis, 1998; Gauhati University, Guwahati, Assam, India.

9. Nath, D. A statistical study of pattern of ante mortem burn injuries. MD thesis, 2007; Gauhati University, Guwahati, Assam, India.

10. Mazumder A, Patowary A. A Study of Pattern of Burn Injury Cases. JIAFM. 2013;35(1):44-46

11. Adamo C, Esposito G, Lissia M, Vonella M, Zagaria N, Scuderi N. Epidemiological data on burn injuries in Angola: a retrospective study of 7230 patients. Burns. 1995;21:536-538.

12. Gupta M, Gupta OK, Yaduvanshi RK, Upadhyaya J. Burn epidemiology in Pink city scene. Burns. 1993;22:47-51.

13. Mangal HM, Pathak A, Rathod JS. The Fire is Both "A Blessing \& Scourge to the Mankind.” JIAFM. 2007;29(4):7577.

14. Harish D, Kaur C, Singh A, Kumar A: A Comprehensive Analysis of Deaths due to Burns in a Tertiary Care Centre. $J$ Punjab Acad Forensic Med Toxicol, 2013;13(2):68-73.
15. Gaffar UB, Husain M, Rizvi SJ: Thermal Burn: An Epidemiological Prospective Study. J Indian Acad Forensic Med. 2008;30(1):10-14.

16. Mishra PK, Tomar J, Sane MR, Saxena D, Yadav A. Profile of Death in Burn Cases: A Post-mortem Study. JIAFM. 2016;38(1):8-10.

17. Chawla R, Chanana A, Rai H, Aggarwal AD, Singh H, Sharma G: A Two-year Burns Fatality Study. J Indian Acad Forensic Med. 2010;32(4) 292-297.

18. Ande JD, Kumar SV, Satyadev M, Tirumala N, Guguloth K, Chandana N: Pattern of Thermal Burn Injuries and their outcomes at Burn Care Unit of Tertiary Hospital, Warangal, Andhra Pradesh, India. Int J Pharm Sci Lett. 2013;3(6):288295.

19. Chaudhary BL, Yadav P, Kumar M, Rahul B: Mortality Profile of Burn Injuries: A Postmortem Study in Lady Hardinge Medical College, New Delhi. J Indian Acad Forensic Med. 2013;35(2):123-126.

20. Bangal RS: Thermal Injuries-A study of mortality patterns. JFMT. 1995;XII(1\&2):1-4.

How to cite this article: Pateria $D$, Thakur $P$. S, Agrawal R, Singh B. K, Tomar J. Autopsy based profile of death in burn cases- One year prospective study. Indian $\mathrm{J}$ Forensic Community Med. 2018;5(4):236-239. 